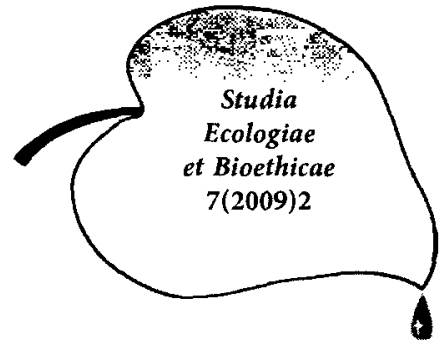

\title{
Diagnoza i rewalidacja osoby niepełnosprawnej. Studium przypadku
}

\begin{abstract}
Wstęp
Wystąpienie to poświęcone jest młodej osobie - Andrzejowi. aktualnie uczęszcza on do gimnazjum. Wykryto u niego upośledzenie umysłowe w stopniu umiarkowanym. Ponadto Andrzej choruje na padaczkę. Fizycznie chłopiec, w wyglądzie zewnętrznym, nie zdradza żadnych odchyleń od normy, wygląda na osobę zdrową. Można $z$ nim porozmawiać na temat spraw życia codziennego, obowiązków domowych. Jednakże jeśli poruszy się tematy dotyczące zagadnień z biologii, geografii, fizyki, matematyki chłopiec nie posiada już takiej wiedzy i nie włącza się do dyskusji. Andrzej jest chłopcem spokojnym, towarzyskim, rozmownym, uwielbia oglądać telewizję i grać w piłkę.

Niniejsza praca ukazuje przebieg życia młodego człowieka począwszy od narodzin, poprzez okres, w którym postawiono diagnozę, a następnie funkcjonowanie w rodzinie, szkole, najbliższym środowisku. Powstała dzięki uprzejmości studentów jednej z uczelni w północno-wschodniej Polsce, którzy w ramach przedmiotu Terapia pedagogiczna prowadzili pod moim kierunkiem badania naukowe.
\end{abstract}

\section{Przypadek Andrzeja}

W lutym 1985 roku urodził się Andrzej. Przyszedł na świat jako trzecie dziecko w pełnej, sześcioosobowej rodzinie, składającej się ojca, matki i czwórki dzieci, w rodzinie robotniczej (oboje rodzice z wykształceniem podstawowym). Andrzej urodził się drogami naturalnymi, bez powikłań. Otrzymał 10 punktów w skali Abghara. Był dobrze rozwiniętym niemowlęciem. W okresie ciąży jego matka czuła się dobrze, nie chodziła do lekarza nie wykonywała żadnych badań.

Początkowo dziecko wydawało się rozwijać prawidłowo. Trochę rodziców zaniepokoił fakt, że do drugiego roku życia w ogóle nie mówiło. Potem zaczęło wypowiadać pojedyncze głoski i etykietować swoich najbliższych. Andrzej na 
swoją siostrę Kasię mówił „ka”, a na brata Pawła „pa”. Pierwsze poprawne wyrazy pojawiły się dość późno bo około piątego roku życia. Wcześniej więcej pokazywał niż mówił.

Domownicy zauważyli, że czasami chłopiec nie reagował kiedy do niego mówili, zachowywał się tak jakby drzemał. Podobne sytuacje częściej pojawiały się kiedy kładł się spać. Stawał się nieobecny, był nieprzytomny, nie można było go obudzić. Po pewnym czasie samoistnie odzyskiwał świadomość. Napady pojawiały się dość często.

Dziecko było odporne, nie chorowało, jak inne niemowlęta i małe dzieci. Mimo powyższych niedomagań rodzice nie spodziewali się niczego poważnego. Jednakże niepokojące objawy nasiliły się gdy miał osiem lat i Andrzej został hospitalizowany. Lekarze stwierdzili padaczkę, zaczęto podawać leki i objawy choroby ustąpiły.

Choroba Andrzeja dziwiła rodziców, bowiem matka będąc w ciąży z synem nie przeszła żadnych poważnych chorób, a w rodzinie nikt nie zapadł na padaczkę. Potem zdiagnozowano u Andrzeja wadę wzroku, ustalono wadę wymowy, a także płaskostopie.

Andrzej do szóstego roku życia przebywał w domu z matką, następnie uczęszczał do klasy zerowej. Matka w trakcie przeprowadzonego $\mathrm{z}$ nią wywiadu twierdziła, że jej syn „nie dorósł do zerówki”. Niewiele rozumiał co działo się na zajęciach, prawie się nie odzywał, był nieśmiały.

Dalej kontynuował naukę w pierwszej klasie szkoły podstawowej. Andrzej już od początku bardzo słabo się uczył. Powoli opanowywał materiał. Podczas, gdy rówieśnicy pisali litery, wyrazy, chłopiec dopiero zaczynał pisać, nie nadążał za kolegami.

W domu ma kochającą rodzinę, wsparcie i pomimo trudnej sytuacji materialnej rodziny, dobre warunki do nauki. Pomocą służyła mu siostra Ania, która pomagała mu w nauce. Ćwiczyła z Andrzejem pisanie liter, liczyła z nim kuleczki, guziki, groch. Jednak Andrzej nie miał motywacji do nauki. A zasób słownictwa w dalszym ciągu był ubogi.

Wychowawczyni klasy, nie widząc postępów w nauce u dziecka, w porozumieniu z pedagogiem szkolnym i rodzicami, wysłała Andrzeja na badania specjalistyczne do poradni psychologiczno-pedagogicznej. Diagnoza wykazała upośledzenie umysłowe w stopniu umiarkowanym. Stwierdzono również, że uczeń pracuje bardzo wolno, nieuważnie, niedbale. Ma zaległości w opanowaniu materiału programowego. Ma małą motywację do nauki czytania, pisania i matematyki. A także bardzo wolne tempo przyswajania nowego materiału.

Natomiast badania lekarskie ujawniły płaskostopie, koślawość stóp, niedowidzenie na prawe oko. Zalecono aby chłopiec był pod opieką kilku lekarskich poradni specjalistycznych $w$ tym neurologicznej. 
W połowie roku szkolnego, już po badaniach, Andrzej został przeniesiony do szkoły specjalnej, gdzie kontynuował naukę na poziomie szkoły podstawowej i gimnazjum. Andrzej został tu jednym z lepszych uczniów w klasie, osiągnął duże postępy w nauce, dobrze radził sobie z programem. Dzięki wizytom w poradni foniatrycznej i logopedycznej oraz ćwiczeniom prowadzonym $w$ domu ma poprawną wymowę.

Andrzej z nieśmiałego dziecka stał się odważnym, towarzyskim i komunikatywnym młodym człowiekiem, orientującym się dobrze w codziennych sytuacjach społecznych. Bardzo dobrze funkcjonuje w znanym sobie środowisku. Zna topografię swojego miasta. Świetnie radzi sobie z samoobsługą.

Jest uczniem chętnie słuchającym poleceń nauczyciela. Wykazuje znaczne postępy w czytaniu i pisaniu ze słuchu. Potrafi napisać swoje imię, nazwisko $\mathrm{i}$ adres zamieszkania. Lubi zajęcia plastyczne. Prace plastyczne są bogate w formę, kolorystykę. Andrzej intuicyjnie bardzo dobrze dobiera barwy, kompozycję i przestrzeń. Ma też poczucie estetyki, bowiem prace są czyste, przejrzyste i opracowane do końca.

Andrzej aktywnie uczestniczy również w zajęciach muzycznych, dobrze odtwarza tekst i melodię. Chętnie bierze udział w występach artystycznych. Interesuje się też grą $\mathrm{w}$ tenisa ziemnego. Lubi piłkę nożną, gra w nią z młodszymi kolegami z podwórka. Dotkliwie przeżywa fakt, iż ze względu na stan zdrowia nie może uczestniczyć w zawodach sportowych.

Potrafi poradzić sobie z pracami domowymi, bowiem dobrze obsługuje sprzęt domowy, chętnie i sprawnie przygotowuje proste jedzenie. Chłopak potrafi liczyć na kalkulatorze, ma trudności w opanowaniu pojęć liczbowych. Ma także problem $\mathrm{z}$ dłuższym skupieniem uwagi i słabą pamięć. Rodzina stara się pomagać mu w rozwiązywaniu różnych problemów życiowych.

Andrzej zaczął uczęszczać już do szkoły zawodowej, mimo że padaczka jest przeciwwskazaniem do podjęcia później pracy zawodowej. Dalsza praca nad usprawnieniem ucznia będzie przebiegać w domu.

\section{Zarys programu terapii}

Terapia Andrzeja powinna opierać się przede wszystkim na udoskonaleniu liczenia, bowiem chłopak ma trudności w rozumieniu pojęć matematycznych.

Potrafi powiedzieć, który banknot ma większą wartość, ale nie rozumie dlaczego. Należałoby wyrównać trudności z matematyki, ćwiczyć dodawanie do siebie jednorodnych składników, odejmowanie, mnożenie, dzielenie.

Można zainicjować zabawę w sklep, pocztę, bank, hotel, a następnie powtórzyć to w autentycznej sytuacji. W celu poprawy umiejętności czytania i pisania można zalecić chłopcu składanie karteczek z sylabami w proponowany wyraz. 
Andrzej jako uczeń upośledzony w stopniu umiarkowanym ma trudności ze skupieniem uwagi. W związku $\mathrm{z}$ tym należy ćwiczyć $\mathrm{z}$ nim technikami poprawiającymi koncentrację. Powinno to być zadanie główne dla nauczyciela, do realizacji w trakcie zajęć szkolnych, który powinien sukcesywnie zwiększać ich stopień trudności.

\section{Zakończenie}

Andrzej jest dobrym przykładem na to, że ciężka praca rodziny, nauczycieli, znajomych a przede wszystkim jego samego nie poszła na marne. Bardzo się rozwinął, usamodzielnił. „Orłem nie będzie”, ale w dalszym życiu da sobie radę. Prawdopodobnie będzie miał $w$ tej kwestii o wiele więcej szans niż jego inni niepełnosprawni rówieśnicy. W swoim życiu miał szczęście w nieszczęściu. Rodzice nie wstydzili się choroby swojego dziecka, pokochali zaakceptowali, nie odrzucili a wsparli i pomogli. Trafił na ludzi, którzy go nie skrzywdzili, nie uważali za samotnego, smutnego, źle ubranego, gorszego. Dali mu szansę. Uznali, że mimo swego kalectwa jest wartościowym człowiekiem i tak samo jak osoba pełnosprawna zasługuje na szacunek i uznanie. Należy dołożyć wszelkich staran, by ci, którzy są słabsi i jest im trudniej znaleźli tych, którzy się nad nimi pochylą. A każde dziecko, nawet to pokrzywdzone przez los, ma prawo do szczęścia i swego miejsca w ramionach najbliższych i tych dalszych.

\section{Literatura}

1. Cudak S.: Wychowawcze i emocjonalne funkcjonowanie rodziny z dzieckiem niepełnosprawnym, Wydawnictwo WSzHE, Łódź 2007.

2. Cytowska B., Wilczura B.: Dziecko z zaburzeniami rozwoju, Wydawnictwo Impuls, Kraków 2006.

3. GAJdzICA Z., KLINIK A.: Wątki zaniedbane, nieobecne w procesie edukacji i wsparcia społecznego osób niepełnosprawnych, Wydawnictwo UŚ, Katowice 2004.

4. Gustausson A., Zakrzewska-Manterys Z.: Upośledzenie w spolecznym zwierciadle, Wydawnictwo Żak, Warszawa 1997.

5. KWAŚNIEWSKa G.: Interdyscyplinarne procesy wczesnej interwencji wobec dziecka i jego rodziny, Wydawnictwo UMCS, Lublin 2007.

6. KRUK-Lasocka J., SekuŁowicz M.: Wczesna diagnoza i terapia dzieci z utrudnieniami rozwoju, Wydawnictwo DSzW, Wrocław 2004.

7. Komorska M.: Sytuacja dzieci i młodzieży niepełnosprawnej w społeczeństwie polskim, Wydawnictwo UMCS, Lublin 2000.

8. KaJA B.: Zarys terapii dziecka, Wydawnictwo AB, Bydgoszcz 2001.

9. Kossakowski Cz., ZaOrSKa M.: Dziecko o specjalnych potrzebach edukacyjnych, Wydawnictwo Akapit, Toruń 2000.

10. MACIARz A.: Z teorii i badan społecznej integracji dzieci niepełnosprawnych, Wydawnictwo Impuls, Kraków 1999. 
11. Minilewicz S.: Dziecko z trudnościami w rozwoju, Wydawnictwo Impuls, Kraków 2005.

12. MinczakiewıCz E.: Dziecko niepełnosprawne, rozwój i wychowanie, Wydawnictwo Impuls, Kraków 2003.

13. O'REGAN F.: Jak pracować z dziećmi o specjalnych potrzebach edukacyjnych, Wydawnictwo K.E. Liber, Warszawa 2005.

14.PIsUla E.: Psychologiczne problemy rodziców dzieci z zaburzeniami rozwoju, Wydawnictwo UW, Warszawa 1998.

15.PeCYNa M.: Psychologia kliniczna a praktyka pedagogiczna, Wydawnictwo Żak, Warszawa 1998.

16. Rakowska A.: Język, komunikacja, niepełnosprawność, Wydawnictwo AP, Kraków 2003.

17.SAкошісz-Вововуко A.: Rodzina jako realizator potrzeb rehabilitacyjnych dzieci niepełnosprawnych, Wydawnictwo Trans Humana, Białystok 2005.

18.Szczygię B.: Jak pracować z dzieckiem niepełnosprawnym, Wydawnictwo Impuls, Kraków 2001.

19. WyCzesany J.: Pedagogika upośledzonych umysłowo, Wydawnictwo Impuls, Kraków 2002.

20.ZABEOCKI K., BREJNIAK W: Wybrane problemy dzieci i młodzieży ze specjalnymi potrzebami rozwojowymi w procesie edukacji, Wydawnictwo UKSW, Warszawa 2004. 